\title{
BADANIA DEMOGRAFICZNE NAD LUDŹMI STARYMI W LUBELSKIEM W ŚWIETLE METRYK ZGONÓW (WYBRANE ASPEKTY). CZĘŚĆ I. KURÓW (1698-1825)
}

\author{
Pokoy twoy ziemia, dom, sklep, abo piwnic[a] \\ Ozdoba mary, a łuszko tarcica \\ Robak towarzysz siedmiołokci sza[ta] \\ Taka wysługa mizernego świat[a] ${ }^{1}$
}

W dorobku historiografii polskiej brak jak dotąd monografii poświęconej ludziom starym ${ }^{2}$. Faktem jednak jest rosnąca w ostatnich latach liczba publikacji zajmujących się znaczeniem, pozycją społeczną i ekonomiczną osób starych ${ }^{3}$. Rozważania te prowadzone są w tle bardziej obszernych dywagacji nad cyklem trwania życia ludzkiego, funkcjonowaniem gospodarstwa domowego, roli rodziny i pozycji jej członków ${ }^{4}$.

* Piotr Rachwał - dr historii, adiunkt w Katedrze Nauk Pomocniczych Historii, Instytut Historii KUL, e-mail: piotrach@kul.pl

${ }^{1}$ Wiersz umieszczony na karcie tytułowej najstarszej zachowanej księgi metrykalnej parafii Piaski. Archiwum Parafialne (dalej: AP) Piaski, Parafia Piaski koło Lublina, zmarłych 1739-1805.

${ }^{2}$ Prace autorów zagranicznych, głównie z Europy Zachodniej, zajmujących się tematyką ludzi starych, wymienia m. in.: M. Kopczyński, Ludzie starzy w chłopskich i szlacheckich gospodarstwach domowych w Koronie u schyłku XVIII wieku, „Kwartalnik Historii Kultury Materialnej” (dalej: KHKM), 58 (2010) nr 1, s. 111-119; C. Kuklo, Gospodarstwo domowe osób starszego pokolenia w miastach na ziemiach polskich w epoce późnofeudalnej, KHKM, 58 (2010) nr 1, s. 121-133.

${ }^{3}$ Rosnące zainteresowanie tematem potwierdzają także konferencje skupiające liczne grono badaczy. Jedną z nich, zatytułowaną: Ludzie starzy w rodzinie i społeczeństwie na ziemiach polskich od XVIII do XX wieku zorganizował w 2012 r. Instytut Historii Uniwersytetu Warszawskiego. Z kolei w maju 2015 r. w Instytucie Historii Uniwersytetu Marii Curie-Skłodowskiej odbyła się międzynarodowa konferencja Dzieciństwo i starość w historiografii.

${ }^{4} \mathrm{Z}$ ważnych prac w tym zakresie należy wymienić: C. Kuklo, Rodzina w osiemnastowiecznej Warszawie, Białystok 1992; C. Kuklo, Kobieta samotna w spoleczeństwie miejskim u schytku Rze- 
Problem starości jest także obecny w pracach autorów śledzących procesy demograficzne zachodzące w lokalnych społecznościach. W śród nich są opracowania poświęcone wsiom i małym miasteczkom, ale też dużym ośrodkom miejskim. Ich wspólnym mianownikiem jest charakter wykorzystanych źródeł (spisy oraz rejestracja ciągła) oraz zastosowane metody badawcze ${ }^{5}$.

czypospolitej szlacheckiej. Studium demograficzno-społeczne, Białystok 1998; tenże, Ludzie starzy w miastach i miasteczkach Rzeczypospolitej szlacheckiej, w: Gospodarka, ludzie, władza. Studia ofiarowane Juliuszowi Łukasiewiczowi w 75. Rocznice urodzin, red. M. Kopczyński, A. Mączak, Warszawa 1998, s. 137-155; tenże, Urodzić się i zestarzeć w mieście polskim, w: Między Zachodem a Wschodem. Studia ku czci profesora Jacka Staszewskiego, t. 2, red. J. Dumanowski, Toruń 2003, s. 345-353; tenże, Gospodarstwo domowe, s. 21-133; D. Daszkiewicz-Ordyłowska, Zgony w parafii toszeckiej w latach 1789-1877, w: „Śląskie Studia Demograficzne”, t. 3: Zgony, red. Z. Kwaśny, Wrocław 1996, s. 27-43 „Śląskie studia demograficzne”, t. 3. Zgony, red. Z. Kwaśny [miejsce i data wydania] s. 121-133; M. Kopczyński, Starossć nie radość? Ludzie starzy na wsi kujawskiej u schytku XVIII wieku, „Zapiski Historyczne”, 61 (1996) s. 45-64; tenże, Cykl życia jednostek na wsi schytku XVIII wieku, „Studia Demograficzne”, 127 (1997) nr 1, s. 97-115; tenże, Studia nad rodzina chtopska w Koronie w XVII-XVIII wieku, Warszawa 1998; L.A. Zyblikiewicz, Kobieta w Krakowie w 1880 r. w świetle ankiet powszechnego spisu ludności. Studium demograficzne, Kraków 1999; M. Szołtysek, D. Biskup, Różnorodność czy tożsamość? Chłopskie gospodarstwo domowe na ziemiach Rzeczypospolitej i Ślaska pod koniec XVIII wieku, w: Rodzina i gospodarstwo domowe na ziemiach polskich $w$ XV-XX wieku. Struktury demograficzne, społeczne i gospodarcze, red. C. Kuklo, Warszawa 2008, s. 363-390; M. Szołtysek, Struktura gospodarstwa domowego w Koronie i na Litwie a funkcje rodziny w końcu XVIII wieku: rozbieżność czy podobieństwo?, w: Rodzina, gospodarstwo domowe i pokrewieństwo na ziemiach polskich w perspektywie historycznej-ciagłość czy zmiana?, red. C. Kuklo, Warszawa 2012, s. 173-208; K. Górna, Śmierć „,ze starości” - o ludziach starych i dlugowiecznych na podstawie wybranych metryk śląskich z XVIII i pierwszej połowy XIX wieku, „Przeszłość Demograficzna Polski” (dalej: PDP), 29 (2010) s. 69-98; P. Guzowski, Starość $w$ życiu kmieci polskich przełomu średniowiecza i czasów nowożytnych, KHKM, 58 (2010) nr 1, s. 101-110; M. Wyżga, Parafia Raciborowice od XVI do końca XVIII wieku. Studium o społeczności lokalnej, Kraków 2011; M. Wyżga, Ludzie starzy w podkrakowskiej parafii Raciborowice w XVIII wieku, w: Społeczno-gospodarcze uwarunkowania i konsekwencje wydtużania życia ludzkiego w Europie Środkowej w czasach nowożytnych, red. H. Kurowska, Zielona Góra 2011, s. 113-121; D.K. Chojecki, Od spoleczeństwa tradycyjnego do nowoczesnego. Demografia i zdrowotność glównych ośrodków miejskich Pomorza Zachodniego $w$ dobie przyspieszonej industrializacji i urbanizacji $w$ Niemczech (1871-1913), Szczecin 2014; R. Poniat, Stużba domowa w miastach na ziemiach polskich od polowy XVIII do końca XIX wieku, Warszawa 2014.

${ }^{5}$ E. Piasecki, Ludność parafii bejskiej (woj. kieleckie) w świetle ksiag metrykalnych z XVIII-XX w. Studium demograficzne, Warszawa-Wrocław 1990; M. Kędelski, Rozwój demograficzny Poznania w XVIII i na początku XIX wieku, Poznań 1992; tenże, Umieralność i trwanie życia ludności Wielkopolski w XIX wieku, Poznań 1996; S. Rejman, Ludność podmiejska Rzeszowa w latach 17841880. Studium demograficzno-historyczne, Rzeszów 2006; G. Liczbińska, Umieralność i jej uwarunkowania wśród katolickiej i ewangelickiej ludności historycznego Poznania, Poznań 2009; H. Kurowska, Gubin i jego mieszkańcy. Studium demograficzne XVII-XIX w., Zielona Góra 2010; M.G. Zieliński, Ludzie starzy i sędziwi w świetle ksiag metrykalnych parafii chetmińskiej z przełomu XVII -XVIII w., w: Kondycja zdrowotna i demograficzna społeczeństwa polskiego na przestrzeni wieków, red. K. Mikulski, A. Zielińska, K. Pękacka-Falkowska, Toruń 2011, s. 106-114; P. Szkutnik, Dtugowieczni mieszkańcy parafii Opole Lubelskie w końcu XVIII wieku w świetle metryk pochówków (pogrzebów), w: Społeczno-gospodarcze uwarunkowania i konsekwencje wydlużania życia ludz- 
Stan wiedzy w omawianym obszarze dla historycznej ziemi lubelskiej, a nawet szerzej pojętej Lubelszczyzny, jest skromny. W pracach Henryka Wiercieńskiego, Marcelego Handelsmana, Zygmunta Sułowskiego, Stanisława Jopa, Janiny Gawrysiakowej, problematyka starości pojawia się marginalnie, głównie przy okazji analizy ruchu naturalnego, próbach odtwarzania struktury wiekowej populacji, czy krytyki źródeł ${ }^{6}$.

Na tle tych opracowań wyróżnia się artykuł Piotra Szkutnika poświęcony długowiecznym mieszkańcom Opola (Lubelskiego) w końcu XVIII stulecia. W oparciu o metryki zgonów z lat 1771-1800 zaprezentowana została struktura wieku zmarłych z podziałem na płeć, miejsce zamieszkania, sezonowość oraz przyczyny zgonów ${ }^{7}$. W konkluzji autor stwierdził, iż wiek zmarłego odnotowywany w metryce nie był precyzyjny i zależał często od subiektywnej oceny wieku zmarłego przez duchownego oraz osób informujących o zaistniałym fakcie. Badania potwierdziły wcześniejsze ustalenia innych autorów, iż sezonowość zgonów warunkowana była m.in. czynnikami bioklimatycznym. Analiza przyczyn zgonów notowanych w metrykach ujawniła także niedoskonałość źródła w tym zakresie, co autor tłumaczy brakiem zainteresowania ze strony osób odpowiedzialnych za dopełnienie formalności oraz niedoskonałością ówczesnej diagnostyki ${ }^{8}$.

Zadaniem niniejszego szkicu jest odpowiedź na pytanie jak liczną grupę zmarłych stanowiły osoby stare zamieszkujące parafię Kurów. W celu odpowiedzi na pytanie, na ile precyzyjne było określanie wieku zmarłych w źródle, zostanie podęta próba jego kontroli. Zajmiemy się także zjawiskiem sezonowości zgonów, $\mathrm{z}$ uwzględnieniem takich różnic $\mathrm{w}$ obrębie populacji ludzi starych, jak płeć $\mathrm{i}$ wiek. W zamierzeniu autora badania nad ludźmi starymi w Lubelskiem uzupełnione zostaną jeszcze $\mathrm{w}$ dwóch artykułach. Jeden poświęcony zostanie parafii wiejskiej Bystrzyca, kolejny, społeczności Lublina. W każdym przypadku podstawę źródłową stanowić będą księgi metrykalne przechowywane w archiwach parafialnych ${ }^{9}$.

kiego w Europie Środkowej w czasach nowożytnych, Zielona Góra 2011, s. 123-147; A. Zielińska, Przemiany struktur demograficznych w Toruniu i na poczatku XX wieku, Toruń 2012.

${ }^{6}$ H. Wiercieński, Opis statystyczny guberni lubelskiej, Warszawa 1901; M. Handelsman, Z. Nagórski, Wieś Bochotnica Kościelna pod względem ludnościowym, cz. 1-2, „Ekonomista”, 4 (1904), s. 44-68, 223-234. Z. Sułowski, Księga zgonów parafi Kijany i Bystrzyca z drugiej połowy XVIII w., „Archiwa Biblioteki i Muzea Kościelne”, 67 (1997) s. 271-299; S. Jop, Ludność na terenie parafii Ostrów Lubelski w ostatniej ćwierci XVIII wieku, PDP, 6 (1974) s. 53-84; J. Gawrysiakowa, Badania demograficzne w parafii Bochotnica Kościelna, PDP, 8 (1975) s. 81-124.

${ }^{7}$ Szkutnik, Dlugowieczni mieszkańcy, s. 123-147.

${ }^{8}$ Tamże, s. 147.

${ }^{9}$ Prezentowane badania stanowią fragment projektu, którego celem jest digitalizacja oraz późniejsze udostępnienie szerokiemu gronu badaczy skanów staropolskich ksiąg metrykalnych z obszaru Lubelszczyzny, a także badania demograficzne nad stanem i ruchem naturalnym ludności. Więcej o projekcie badawczym na stronie: ksiegimetrykalne.pl (dostęp: 29.06.2015 r.). 


\section{Początek starości i jej trwanie}

Odpowiedź na pytanie kogo należy uważać za człowieka starego nie jest jednoznaczna. Wynika to z subiektywnej oceny dotyczącej kondycji biologicznej jednostki. Faktem jest, iż starość jako pewien etap w życiu człowieka nie rozpoczyna się z dnia na dzień, ale jest efektem dłuższego procesu zachodzącego w ustroju człowieka. Stąd sam proces starzenia przebiega u poszczególnych jednostek i grup niejednakowo, u jednych wcześniej u innych później. Dodatkowo starość jest badana z punktu widzenia nie tylko medycyny, ale także przez reprezentantów innych dyscyplin naukowych. Dla socjologów i psychologów taką granicę stanowi koniec aktywności zawodowej, co w dzisiejszych czasach wiąże się z przejściem na emeryturę. Na gruncie socjologii funkcjonuje termin - starośść psychospołeczna. Oznacza ona etap życia, w którym procesy psychiczne, objawiające się rezygnacją i poczuciem braku szans oraz społeczne, polegające na odrzuceniu, zgodnie z istniejącym rytuałem kulturowym, oddziałują synergicznie z procesami biologicznymi, prowadząc do naruszenia homeostazy, a tym samym do ograniczenia możliwości przeciwdziałania wymienionym procesom, bez możliwości substytucji i bez obiektywnych szans na powrót do stanu poprzedniego ${ }^{10}$.

Z kolei dla demografów, zwłaszcza tych zajmujących się populacjami w minionych wiekach, początek starości wyznaczają często kategorie występujące w wykorzystanych źródłach.

Pomimo tych trudności, liczbowe i uniwersalne ustalenie granicy starości wydaje się konieczne, ponieważ umożliwia kwantyfikację problemu, a co za tym idzie pozwala na dokonanie porównań w czasie i przestrzeni. W starożytnych Chinach cykl życia ludzkiego dzielono na siedem faz. Początek fazy szóstej, następującej po końcowym okresie życia twórczego, miał się rozpoczynać w wieku 60 lat i trwać do 70 roku. Ostatnia z kolei faza - siódma określona jako starość, miała rozpoczynać się wraz z ukończeniem 70 roku życia. Według greckiego myśliciela Pitagorasa starość rozpoczynała się po 60 roku życia, podobną granicę wyznaczał też słynny grecki lekarz Hipokrates ${ }^{11}$. Od tak wyznaczanych granic starości nie różnią się zbytnio klasyfikacje znacznie późniejsze. W XIX w. w środowisku fizjologów francuskich dzielono życie ludzkie na cztery okresy, przy czym starość rozpoczynała się w 55 lub 60 roku życia. Ciekawe ujęcie problemu zaproponował jeden z wybitnych reprezentantów wspomnianej szkoły francuskiej Maria Jan Piotr Flourens (1794-1867). Dwie ostanie kategorie (w ośmiostopniowej skali), to tzw. pierwszy okres starości rozpoczynający się w 70 i kończący w 85 roku życia i drugi okres starości po skończeniu 85 roku życia. Znacznie niższy próg zaproponował z kolei fizjolog niemiecki Max Rubner (1854-1932), który ustalił go na 50 lat. $Z$ kolei profesor uniwersytetu we Fryburgu, znany anatomopatolog Ludwik Aschoff (1866-1942) oznaczył początek starości nie przez wskazanie konkretnego roku, ale poprzez określenie przedziału wieku (45-65 rok życia).

${ }^{10}$ J. Staręga-Piasek, A. Lissowski, Starość psychospołeczna, w: Starość psychospołeczna i potrzeby opieki medycznej ludzi starych, Warszawa 1985, . s. 43.

${ }^{11}$ E. Rosset, Proces starzenia się ludności. Studium demograficzne, Warszawa 1959, s. 109-111. 
Ponadto użył terminów - wiek starczy (65-85 rok życia) oraz - sędziwa starość (powyżej 85 roku) ${ }^{12}$.

W ujęciu społecznej demografii historycznej ważnym kryterium wyznaczającym początek starości jest pozycja danej osoby w gospodarstwie domowym. Mało prawdopodobną była sytuacja, w której głową gospodarstwa domowego była osoba niedołężna i schorowana ${ }^{13}$, a przecież taki stan rzeczy często szedł w parze z wiekiem biologicznym. Należy też zauważyć, iż pojęcie starości różniło się w odniesieniu do mężczyzn i kobiet. U tych pierwszych, starość społeczna, związana $\mathrm{z}$ oddaniem gospodarstwa $\mathrm{w}$ ręce następców zaczynała się między 55 a 64 rokiem życia. Z kolei starość kobieca rozpoczynała się wcześniej, w grupie wieku 45-54 lata ${ }^{14}$. Różne kategorie starości w odniesieniu do płci mogły wynikać także z możliwości prokreacyjnych. Z oczywistych powodów próg dla kobiet był znacznie niższy i oscylował wokół 40 lat, dla mężczyzn zaś, nieograniczonych czynnikami natury fizjologicznej, granicę tą umownie ustalano na 60 rok życia ${ }^{15}$.

$\mathrm{Na}$ podstawie przytoczonych wyżej informacji można stwierdzić, że najczęściej wskazywanym wiekiem oznaczającym początek starości było 60 lat. W większości dotychczasowych prac z obszaru szeroko pojętej historii społecznej przyjmuje się zazwyczaj 60 lub 65 rok życia ${ }^{16}$. Na potrzeby naszych badań nad ludnością wybranych parafii w Lubelskiem przyjęliśmy również 60 rok życia jako początek okresu starości.

Na gruncie demografii, w kontekście badań nad wiekiem populacji, używa się często terminów dlugość życia, przeciętne dalsze trwanie życia oraz normalne trwanie życia.

Pierwsze z określeń oznacza maksymalny wiek, którego człowiek może dożyć w optymalnych warunkach. Wiadomo, że długość życia determinowana jest procesem starzenia się, powiązanym z procesem zaniku reprodukcji komórek. Medycyna nie dostarcza nam jednoznacznych odpowiedzi jaki jest limit lat życia ludzkiego. Rzadko pojawiają się udokumentowane informacje o osobach, które żyły około 120 lat. Najstarszy taki przypadek dotyczy Jeanne Louise Calment, która przyszła na świat we Francji w 1875 r., a zmarła w 1997 roku ${ }^{17}$.

Terminu przeciętne dalsze trwanie życia używa się z kolei na określenie średniej liczby lat, jaką ma jeszcze do przeżycia osoba w określonym wieku, przy założeniu stałego poziomu umieralności z okresu, dla którego opracowano tablice trwania życia. Zmiany w wartościach przeciętnego dalszego trwania życia są odzwierciedleniem zmian w poziomie umieralności, a te z kolei są efektem popra-

\footnotetext{
${ }^{12}$ Rosset, Proces starzenia, s. 111-113.

${ }^{13}$ Kuklo, Ludzie starzy, s. 137-155.

${ }^{14}$ Kopczyński, Studia nad rodzina, s. 150 i nn.

${ }^{15}$ Zielińska, Przemiany struktur, s. 290-291.

${ }^{16}$ Kuklo, Ludzie starzy, s. 141; Górna, Śmierć „,ze starości”, s. 71-72.

${ }^{17}$ J. Balicki, E. Frątczak, Ch. B. Nam, Przemiany ludnościowe. Fakty-interpretacje-opinie,
} Warszawa 2007, s. 122. 
wy (lub pogorszenia) współczynników umieralności w poszczególnych grupach wieku $^{18}$.

Pojęcie normalne trwanie życia oznacza wiek, na który przypada największa intensywność zgonów w starszym wieku. Innymi słowy mówiąc, jest to wiek, któremu odpowiada największa liczba zgonów (dominanta zgonów) ${ }^{19}$.

\section{Parafia Kurów}

Pierwsza wzmianka na temat kościoła kurowskiego pochodzi z 1185 r., nie wiadomo jednak czy odnosi się ona także do parafii. Sam dokument erekcyjny nie zachował się do naszych czasów. Wiadomo natomiast, że parafia funkcjonowała w XV w., a w następnym stuleciu działała szkoła oraz szpital dla ubogich ${ }^{20}$.

W 1553 r. wikariusz ks. Mikołaj wprowadził przy poparciu dziedzica kurowskiego Abrahama Zbąskiego nabożeństwo kalwińskie, przekształcając kościół w zbór. W tym czasie w pobliżu funkcjonowały tylko dwa kościoły katolickie: w Wąwolnicy i Końskowoli. Parafia kurowska znalazła się pod administracją plebana wąwolnickiego. Bogusław Jan Zbąski w 1628 r. ponownie przywrócił obrządek rzymskokatolicki w kościele kurowskim, a proboszczem został ks. Jan Florkiewicz ${ }^{21}$. Po najeździe szwedzkim w połowie XVII w. wraz z odbudową gospodarczą, nastąpił dalszy rozwój życia religijnego. Działało bractwo różańcowe, a plebani posiadali tytuł prepozyta. Kolejnymi proboszczami byli ks. Jan Lisiecki, a od 1679 r. ks. Stanisław Borysławski, który korzystał z pomocy wikariusza. W czasie gdy włodarzem parafii był ks. Franciszek Garzyński, biskup krakowski Stanisław Szembek 15 października 1690 r. dokonał konsekracji nowego, murowanego kościoła parafialnego. W 1759 r. biskup Kajetan Sołtyk ustanowił przy parafii 4 mansjonarzy, którzy mieli wspierać proboszcza w wypełnianiu posługi duszpasterskiej. Do ich obowiązków należało prowadzenie niedzielnej nauki oraz sprawowanie sakramentów, a także celebracja eucharystii w określonych intencjach $^{22}$. W czerwcu 1775 r. nowym proboszczem został ks. Grzegorz Piramowicz, postać wybitna, znana szerzej z zaangażowana w prace Komisji Edukacji Narodowej. W czasie jego posługi poprawie uległa kondycja ekonomiczna parafii. Założono folwark, wybudowano stajnie i stodoły, działalność rozpoczęła nowa szkoła

${ }^{18}$ Balicki, Frątczak, Ch. B. Nam, Przemiany ludnościowe, s. 123. W dobie płodności naturalnej, która trwała na ziemiach polskich jeszcze w XIX w., przy wysokim współczynniki zgonów dzieci najmłodszych, przeciętne oczekiwane trwanie życia $\left(\mathrm{e}_{\mathrm{o}}\right.$ ) było stosunkowo niskie. W parafii Bejsce, w latach 1801-1810 wynosiło niespełna 30 lat dla chłopców i ponad 31 lat dla dziewczynek. Z kolei przeciętne oczekiwane trwanie życia dla osób w wieku 60 lat było zbliżone dla obu płci i wynosiło ok. 6,5 roku. Piasecki, Ludność parafii, s. 282. W prowincji poznańskiej, w połowie XIX wieku, po przekroczeniu progu starości (60 lat) mężczyźni mieli przed sobą średnio 10,3 lat życia, a kobiet 9,4. Kędelski, Umieralność i trwanie, s. 103.

${ }^{19}$ Balicki, Frątczak, Ch. B. Nam, Przemiany ludnościowe, s. 125.

${ }^{20}$ P. Szafran, Rozwój średniowiecznej sieci parafialnej w Lubelskiem, Lublin 1958, s. 151-152.

${ }^{21}$ Sama wspólnota kalwińska funkcjonowała dalej, a jej upadek nastąpił prawdopodobnie po najeździe szwedzkim w 1655 roku. Zob. M. Jaworski, Dzieje parafii rzymskokatolickiej w Kurowie w latach 1773-1976, Lublin 1991, s. 15 (mps pracy mgr w Archiwum Uniwersyteckim KUL).

${ }^{22}$ S. Wójcicki, Dziedzictwo kulturowe gminy Kurów, Kurów 2012, s. 133. 
elementarna. Po ks. Grzegorzu Piramowiczu, w lutym 1799 r., funkcję proboszcza kurowskiego objął jego brat Stanisław. Ostatnim proboszczem w omawianym przez nas okresie był ks. Wincenty Pieńkowski (późniejszy biskup lubelski), który sprawował urząd w latach 1823-185323.

Parafia obejmowała początkowo obok miasta Kurów wsie: Płonki, Brzozową Gać i Wolicę. Z kolei wizytacja z 1709 r. wymienia dodatkowo: Szumów, Paluchów i Glinki, w wykazie brakuje już wsi Płonki. W 1803 r. obok wyżej wymienionych do parafii należały: wieś Podbórz, część Dęby i Łąkoci oraz nowo wybudowany dwór kurowski w Olesinie. Te same miejscowości wymieniono w wizytacji z 1830 roku $^{24}$. Administracyjnie parafia należała do dekanatu kazimierskiego, archidiakonatu lubelskiego. W 1799 r. w miejsce dekanatu kazimierskiego utworzono dwa nowe: w Zaklikowie i w Kurowie. Po utworzeniu w 1805 r. diecezji lubelskiej dekanat kurowski znalazł się w jej granicach. Stan taki trwał do $1818 \mathrm{r}$. kiedy to reaktywowano dekanat kazimierski ${ }^{25}$.

Parafia miała charakter miejsko-wiejski. Najważniejszym ośrodkiem był Kurów, lokowany na prawie magdeburskim w 1442 roku. Pod względem liczby mieszkańców w XVI i XVII w. Kurów dorównywał takim miastom jak: Kraśnik, Lubartów, Janów, Łęczna, Opole czy Garbów. W świetle spisu mieszkańców miast z 1787 r. Kurów był zamieszkany przez 1902 osoby, w tym 871 Żydów, co według T. Opasa sytuowało to miasto w gronie największych ośrodków na Lubelszczyźnie $^{26}$. Według spisu diecezji krakowskiej z 1787 r. cała parafia liczyła 3068 osób, w tym 908 Żydów $^{27}$. Z kolei statystyki z 1827 r. informują o 1988 mieszkańcach miasta, w tym $1090 \dot{Z ̇ y d a c h}^{28}$.

Podstawą utrzymania mieszkańców parafii było rolnictwo, wyjątkiem był sam Kurów, w którym dużą rolę odgrywało też rzemiosło i handel. Szczególną pozycję wśród rzemieślników zajmowali tu szewcy. W 1563 r. otrzymali oni przywilej od ówczesnego właściciela Kurowa Stanisława Zbąskiego. Potwierdzany przez późniejszych właścicieli miasta zezwalał na tworzenie jatek i sprzedawanie wyrobów na targach i jarmarkach w okolicznych miejscowościach. W mieście działały także cechy: bednarski, kowalski, kuśnierski, tkacki i rzeźnicki ${ }^{29}$. Znaczną pozycję w działalności gospodarczej miasta jak i całej parafii, zajmował folwark kurowski. Zajmował on powierzchnię ok. 20 włók. W uprawę gruntów

${ }^{23}$ Jaworski, Dzieje parafii, s. 83-84.

${ }^{24}$ M. Jaworski, Dzieje parafii rzymskokatolickiej w Kurowie w latach 1773-1976, Lublin 1991, s. 21-22 (mps pracy mgr w Archiwum Uniwersyteckim KUL).

${ }^{25}$ Jaworski, Dzieje parafii, s. 23.

${ }^{26}$ T. Opas, Sytuacja ludności żydowskiej w miastach szlacheckich województwa lubelskiego w XVIII wieku, „Biuletyn Żydowskiego Instytutu Historycznego”, 62 (1968) s. 24.

${ }^{27}$ Kościót i spoleczeństwo Małopolski w II połowie XVIII w. Materiaty źródtowe, t. 1, Ludność i organizacja diecezji krakowskiej, oprac. B. Szady, Lublin 2010, s. 103.

${ }^{28}$ F. Rodecki, Tabella miast, wsi, osad Królestwa Polskiego z wyrażeniem ich położenia i ludności alfabetycznie ułożona w Biórze Kommissyi Rzadowey Spraw Wewnętrznych i Policyi, Warszawa 1830.

${ }^{29}$ K.A. Boreczek, Kurów od początku XVIII do połowy XX wieku. Część pierwsza 1700-1918, Kurów 1996, s. 43-45; Jaworski, Dzieje parafii, s. 5. 
pańskich zaangażowane były wsie: Płonki, Brzozowa Gać, Szumów, Paluchów, Dęba, Glinnik i część Łąkoci oraz - do 1786 r. - mieszczanie Kurowa. Jak wynika z ksiąg miejskich, pod koniec XVIII w. tylko trzech mieszkańców Kurowa zajmował się rolnictwem. Za pozwoleniem Ignacego Potockiego grunty miejskie mogły być nabywane przez mieszkańców wsi należących do klucza kurowskiego. W świetle danych z 1796 r. place miejskie posiadało 8 osób z Płonek, 11 osób z Brzozowej Gaci oraz 6 osób z Szumowa ${ }^{30}$. Do ważnych przeobrażeń w życiu gospodarczym doszło po zajęciu Lubelszczyzny przez Austriaków, następnie w czasach Księstwa Warszawskiego, a później Królestwa Polskiego. W wyniku tych zmian chłopi uzyskali wolność osobistą, zmieniły się też zasady funkcjonowania organizacji cechowych. Przez cały XIX w. dominującym rzemiosłem w Kurowie pozostało nadal szewstwo ${ }^{31}$.

W badanym okresie parafia kurowska doświadczyła wielokrotnie niszczących skutków działań zbrojnych i klęsk żywiołowych. Podczas wojny północnej parafię niszczyły wojska szwedzkie, saskie, koronne i rosyjskie. Z mieszkańców Kurowa ściągano kontrybucje, palono domy, mordowano. Opis takich wydarzeń znajdziemy m. in. na kartach parafialnych ksiąg metrykalnych. W księdze ochrzczonych pod 1707 r. ówczesny proboszcz zanotował, iż wskutek najazdu obcych wojsk, nazwanych barbarorum orientalium ludność Kurowa została częściowo wymordowana, część zaś uciekła i rozproszyła się 32 W 1717 r. w okolicach Kurowa miały miejsce starcia między wojskami konfederatów tarnogrodzkich a oddziałami feldmarszałka Fleminga. Po wyparciu konfederatów miejscowa ludność został obarczona utrzymaniem żołnierzy rosyjskich. Znacznych zniszczeń dokonała także armia rosyjska w okresie elekcji Augusta III Sasa. Z kolei w okresie stanisławowskim mieszkańcy parafii byli świadkami wydarzeń wojny polsko-rosyjskiej z 1792 r. oraz insurekcji kościuszkowskiej33.

Dramatyczny dla miasta był rok 1799.5 czerwca tegoż roku wybuchł pożar, w którym spłonęło blisko połowa wszystkich budynków. Najbardziej ucierpiała wschodnia i północna część miasta, ocalał natomiast kościół parafialny ${ }^{34}$. Wszystkie te tragiczne wydarzenia negatywnie odbijały się na ludności, której spadek były charakterystyczny dla całego woj. lubelskiego. W latach 1810-1819 odnotowano wyraźny ubytek ludności, przy ogólnym wzroście występującym w tym czasie na terenie całego Królestwa Polskiego. Część tych strat była spowodowana zniszczeniami wojennymi, część wzmożoną migracją zarobkową na zachód Królestwa, a szczególnie na tereny województwa kaliskiego i mazowieckiego ${ }^{35}$.

${ }^{30}$ Boreczek, Kurów, s. 47-48, 104.

${ }^{31}$ Tamże, s. 103.

${ }^{32}$ Archiwum Parafialne (dalej: AP) Kurów, [Liber metrices baptisatorum ab anno 1691], (tytuł księgi w nawiasie kwadratowym oznacza jego brak w źródle, dla identyfikacji serii zapisu został on nadany w ujednoliconym brzmieniu, z oznaczeniem roku w którym rozpoczynają się wpisy) s. 162.

${ }^{33}$ Boreczek, Kurów, s. 54-57.

${ }^{34}$ Tamże, s. 60.

${ }^{35}$ W. Śladkowski, Pod zaborem austriackim, w Księstwie Warszawskim i Królestwie Polskim 1795-1831, w: Dzieje Lubelszczyzny, t. 1, red. T. Mencel, Warszawa 1974, s. 492. 


\section{Podstawa źródłowa}

Najstarsze księgi metrykalne parafii Kurów przechowywane w archiwum parafialnym pochodzą z pierwszej połowy XVII w. Pierwsze wpisy ochrzczonych datowane są na wrzesień 1628 roku $^{36}$ Nieco późniejsza jest księga zaślubionych, która rozpoczyna się zapisami z października 1690 roku $^{37}$. W przypadku ksiąg zgonów, stanowiących podstawę naszych badań, najstarsze wpisy pochodzą z maja 1698 roku. Księga ma format dutki, oprawiona jest w płótno. Karta tytułowa, kilka początkowych, a także dwie ostatnie mają niewielkie ubytki, część z nich uzupełniono papierem. Wewnątrz woluminu znajdują się ślady zacieków, a atrament wyblakł, co utrudnia częściowo odczytanie treści. Wpisów dokonano po łacinie, według formularza trydenckiego ${ }^{38}$. Każda z kart została także opieczętowana przez dziekana kazimierskiego, co jest pozostałością po wizytacji z 1854 roku. Zapisy kończą się na listopadzie 1747 roku $^{39}$. Kolejny tom zawiera metryki z lat 1746-1778, ma format dutki, oprawiony jest w płótno. Językiem zapisu była łacina. Ze względu na zły stan zachowania, część kart wzmocniono bibułą japońską. Odczytanie części zapisów jest utrudnione z powodu przebarwień atramentu. Podobnie jak w najstarszej księdze na każdej karcie znajduje się pieczęć dziekana kazimierskiego ${ }^{40}$. Trzecia w kolejności księga zawiera metryki począwszy od stycznia 1782 r. do grudnia 1811 roku. Stan zachowania księgi jest znacznie lepszy od dwóch wyżej wymienionych, inny jest też format, w tym przypadku - pełny arkusz. Językiem zapisu pozostała łacina, zmienił się natomiast formularz. Począwszy od 1782 r. metryki sporządzano w formie rubrykowanej (rysowane odręcznie), zawierają one kolejno: nazwę miejscowości z której pochodził zmarły, rok zgonu, miesiąc i dzień pogrzebu, imię, pochodzenie i wiek zmarłego, imiona i nazwisko rodziców zmarłego (sporadycznie tylko informacja ta pojawiała się gdy zmarły był osoba dorosłą), przyczynę zgonu, informację o udzielonych sakramentach, personalia świadków zgłaszających zgon. Taki formularz obowiązywał do 1791 r., po czym powrócono do zapisów według formularza trydenckiego ${ }^{41}$. Pomiędzy tomem drugim i trzecim występuje przerwa w rejestracji która obejmuje trzy lata. Konfrontacja współcześnie przechowywanych ksiąg metrykalnych ze stanem archiwum w połowie XIX w. pozwoliła usta-

${ }^{36}$ AP Kurów, [Liber metrices baptisatorum ab anno 1628].

${ }^{37}$ AP Kurów, [Liber metrices copulatorum ab anno 1690].

${ }^{38}$ Wśród XVII-wiecznych wpisów znajdują się dwa sporządzone w języku polskim, co stanowiło bardzo rzadką praktykę. Analiza duktu pisma wskazuje, że zapisy zostały sporządzone tą samą ręką, którą odnotowano zgony innych osób. Użycie w tych konkretnych przypadkach języka polskiego trudno wytłumaczyć, być może pochodzenie i status osób zmarłych zadecydował, iż nie zostały one potraktowane jako pełnoprawni członkowie lokalnej społeczności i w ten sposób wyróżnione spośród pozostałych parafian. W pierwszym przypadku chodzi o osobę pochodzącą z jednej z miejscowości parafialnych, lecz nie mającej prawdopodobnie stałego miejsca zamieszkania ani źródła utrzymania. Druga metryka podaje co prawda imię i profesję zmarłego, określa go jednak mianem ,podróżny”. AP Kurów, [Liber metrices baptisatorum ab anno 1628], s. 7.

${ }^{39}$ AP Kurów, [Liber metrices mortuorum ab anno 1698].

${ }^{40}$ AP Kurów, [Liber metrices mortuorum ab anno 1748].

${ }^{41}$ AP Kurów, Liber metrices mortuorum ecclesiae parochialis Kuroviensis ab anno 1782 ad annum 1811. 
lić, iż brakujące wpisy dla okresu 1779-1781 tworzyły odrębną księgę o objętości 166 stron $^{42}$. Czwarta księga rozpoczyna się wpisami ze stycznia 1797 r., a kończy na grudniu 1808 roku. Cały tom prowadzony był według drukowanego formularza austriackiego i zawierał kolejno: dokładną datę zgonu, numer domu zmarłego, jego personalia, wyznawaną religię, płeć, wiek, a w ostatniej rubryce status społeczny oraz przyczynę zgonu ${ }^{43}$.

Pozostałą grupę źródeł tworzą księgi w formacie pełnego arkusza, prowadzone według tzw. formularza napoleońskiego. Nowy formularz, który zaczął obowiązywać od 1810 r. różnił się co do formy od znanego z ustawodawstwa austriackiego. Zapisy miały być sporządzane w języku polskim, odstąpiono od rubrykowania ksiąg na rzecz jednolitego zapisu. W księdze zgonów należało odnotować: dokładną datę i godzinę sporządzenia aktu, imię, nazwisko i tytulaturę kapłana dokonującego wpisu, imię i nazwisko osoby zgłaszającej fakt śmierci, personalia zmarłego wraz z podaniem jego wieku, zawodu, miejsca zamieszkania oraz informacją o bliskich osobach które pozostawił. W przypadku zamężnych kobiet podawano także nazwisko panieńskie. Na końcu znajdował się podpis księdza oraz świadków ${ }^{44}$.

W zachowanym materiale źródłowym, oprócz wyżej wspomnianej luki za lata 1779-1781 występują dłuższe lub krótsze przerwy w rejestracji, spowodowane bądź przez ubytki kart lub ich miejscowe zniszczenia, bądź też zaniechania ze strony osób odpowiedzialnych za prowadzenie metryk. Braki takie w najstarszej zachowanej księdze zgonów dotyczą okresu: od lutego 1704 r. do listopada 1709 r. włącznie, od marca 1710 r. do września 1721 r., od sierpnia do grudnia 1722 r., od marca do października 1723 r., od marca do grudnia 1724 r., od stycznia 1725 (z wyjątkiem jednego zapisu z czerwca) do marca 1730 r., od lipca 1730 do grudnia 1734 r., od czerwca do grudnia 1735 roku $^{45}$. W księdze trzeciej, zawierającej akty zgonów częściowo $\mathrm{w}$ formie tabel, częściowo według formularza trydenckiego, znajduje się luka we wpisach z okresu od 1797 r. do września 1800 roku $^{46}$. Braki te uzupełnia księga formularza austriackiego zaczynająca się od 1797 r., która zawiera wpisy zgonów do 1808 roku $^{47}$. Akty z okresu od października 1800 r. do końca 1808 r. pokrywają się liczebnie w obu księgach (prowadzono je równolegle).

Praktyka rejestracji wieku zmarłego ewoluowała wraz z upływem czasu. Pierwotnie informacje o wieku zmarłego pomijano, sporadycznie używano określeń typu infans, virgo, senex; do wyjątków zaś należały bardziej precyzyjne określenia. Pierwszy i jedyny taki zapis dla 1698 r. dotyczył dziewczynki zmarłej

${ }^{42}$ AP Kurów, [Liber natorum ab anno 1807], s. 198-200.

${ }^{43}$ AP Kurów, Liber mortuorum ecclesiae Kurowiensis ab anno 1797 ad annum 1809.

${ }^{44}$ AP Kurów, [Księgi zgonów od 1812 do 1825 roku] (dla każdego roku oddzielny wolumin). Więcej na temat zasad rejestracji metrykalnej na omawianym terenie zob.: J. Gawrysiakowa, Grupy wyznaniowe ludności w Lubelskiem w XIX wieku, Lublin 1992.

${ }^{45}$ AP Kurów, [Liber metrices baptisatorum ab anno 1628].

${ }^{46}$ AP Kurów, Liber metrices mortuorum ecclesiae parochialis Kuroviensis ab anno 1782 ad annum 1811.

${ }^{47}$ AP Kurów, Liber mortuorum ecclesiae Kurowiensis ab anno 1797 ad annum 1809. 
w wieku trzech tygodni ${ }^{48}$. Do początku lat 20 XVIII w. liczba osób zmarłych z odnotowanym wiekiem zwiększała się, ale poza jednym przypadkiem (33 letni mężczyzna zmarły w lutym 1700 r.) były to informacje o zgonie dzieci (najstarsze miało 11 lat). Rejestrowanie wieku denata upowszechniło się od 1721 r. co obrazuje tabela 1 . Uwagę zwracają lata 60 . XVIII w., kiedy to w $100 \%$ określono wiek zmarłych. Po przeciwnej stronie znalazła się pierwsza dekada XVIII w., wówczas wiek odnotowano dla niespełna 3\% zmarłych.

Tabela 1. Odsetek zmarlych $\mathrm{z}$ podanym wiekiem/ The percentage of the dead with the specified age.

\begin{tabular}{|c|c|c|c|}
\hline Lata & $\begin{array}{c}\text { \%o zgonów } \\
\text { z odnotowanym } \\
\text { wiekiem }\end{array}$ & Lata & $\begin{array}{c}\text { \% zgonów } \\
\text { z odnotowanym } \\
\text { wiekiem }\end{array}$ \\
\hline $1698-1700$ & 12,90 & $1771-1780$ & 98,39 \\
\hline $1701-1710$ & 2,67 & $1781-1790$ & 99,46 \\
\hline $1721-1730$ & 83,08 & $1791-1800$ & 97,98 \\
\hline $1731-1740$ & 87,36 & $1801-1810$ & 98,67 \\
\hline $1741-1750$ & 84,88 & $1811-1820$ & 98,36 \\
\hline $1751-1760$ & 90,81 & $1821-1825$ & 99,38 \\
\hline $1761-1770$ & 100,00 & - & - \\
\hline
\end{tabular}

Źródło: AP Kurów: [Liber metrices mortuorum ab anno 1698]; [ Liber metrices mortuorum ab anno 1748]; Liber metrices mortuorum ecclesiae parochialis Kuroviensis ab anno 1782 ad annum 1811; [Liber natorum ab anno 1807]; [Księgi zgonów od 1812 do 1825 roku].

\section{Liczba zmarlych}

W sumie w badanym okresie zmarło 6633 osoby, wiek zmarłego odnotowano w 94,8\% przypadków. Liczba odnotowanych zmarłych w ciągu roku wynosiła od $1 \mathrm{w} 1704$ r. do $174 \mathrm{w} 1810$ roku. Rocznie umierało średnio 64 osoby ${ }^{49}$. Liczba zmarłych którzy osiągnęli przynajmniej 60 rok życia wyniosła natomiast 1030 osób, co stanowiło 16,4\% ogółu zmarłych ${ }^{50}$.

Posługując się tego typu statystyką zawsze należy pamiętać o możliwej niedoskonałości źródła w tym zakresie. W opinii wielu badaczy statystyka zgonów, zwłaszcza w okresie staropolskim, była obciążona największymi brakami. Jedną z miar pozwalających określić stopień tej niedokładności jest wskaźnik dynamiki demograficznej - U/Z (liczba urodzeń przypadająca na jeden zgon) ${ }^{51}$.

${ }^{48}$ AP Kurów, [Liber metrices mortuorum ab anno 1698], s. 5.

${ }^{49}$ Jest to liczba zaniżona, pod uwagę trzeba wziąć, iż dane dla kilku lat są niepełne.

${ }^{50} \mathrm{~W}$ niedaleko od Kurowa położonej parafii Opole udział osób zmarłych w stosunku do wszystkich zgonów kształtował się na poziomie 17,8\%. Szkutnik, Dlugowieczni mieszkańcy, s. 134; Por.: Kuklo, Demografia Rzeczpospolitej, s. 406-408.

${ }^{51}$ Więcej na ten temat: I. Gieysztorowa, niebezpieczeństwa metodyczne polskich badan metrykalnych XVII-XVIII wieku, KHKM, 19 (1971) s. 557-603. 
Tabela 2. Wskaźnik Urodzenia/Zgony w parafii Kurów w latach 1701-1825/ Birth and death rate in the parish of Kurów in the years 1701-1825.

\begin{tabular}{|c|c|c|c|}
\hline Lata & $\mathrm{U} / \mathrm{Z}$ & Lata & $\mathrm{U} / \mathrm{Z}$ \\
\hline $1701-1710$ & 9,5 & $1771-1780$ & 2,0 \\
\hline $1711-1720$ &. & $1781-1790$ & 1,2 \\
\hline $1721-1730$ & 15,0 & $1791-1800$ & 1,3 \\
\hline $1731-1740$ & 3,7 & $1801-1810$ & 1,1 \\
\hline $1741-1750$ & 3,3 & $1811-1820$ & 1,1 \\
\hline $1751-1760$ & 2,2 & $1821-1825$ & 1,5 \\
\hline $1761-1770$ & 2,4 & - & - \\
\hline
\end{tabular}

Źródło: patrz tab. 1; [Liber metrices baptisatorum ab anno 1628]; [Liber metrices baptisatorum ab anno 1691]; [Liber metrices baptisatorum ab anno 1769]; [Liber metrices baptisatorum ab anno 1782]; [Liber natorum ab anno 1797]; [Księgi urodzeń od 1810 do 1825 roku]

Zważywszy, iż poprawna rejestracja powinna charakteryzować się wskaźnikiem na poziomie 1 lub niewiele go przekraczać, uzyskane wartości dla pierwszej połowy XVIII w. wskazują na duże braki (tab. 2). Pewną poprawę statystyki można zaobserwować od lat 30. XVIII w., co koreluje ze znacznym wzrostem surowych liczb zgonów. Poziom wskaźnika uznawany za prawidłowy osiągnięty został dopiero w latach 80. XVIII wieku. Należy o tym pamiętać, przy formułowaniu wniosków płynących z dalszej analizy danych.

Uwzględniając wcześniejsze uwagi dotyczące notowania wieku zmarłego w najstarszej zachowanej księdze metrykalnej, badanie wieku osób starych w chwili zgonu rozpoczniemy od lat 20 . XVIII wieku. Stosowne zestawienie prezentuje tabela 3. Najliczniejszą grupę zmarłych stanowiły osoby w wieku 60-69 lat, co w oczywisty sposób wynika ze struktury wiekowej populacji i odpowiadającym im poziomom śmiertelności. Dominanta wieku w jakim umierali ludzie starzy wyniosła 60 lat. Oszacowanie poziomu umieralności w przypadku osób dorosłych w dobie prestatystycznej jest praktycznie niemożliwe, w związku z tym, iż rzadko kiedy dysponujemy danymi o strukturze wieku danej populacji.

Tabela 3. Zgony w wieku 60 lat i więcej w ujęciu miesięcznym, z podziałem na płeć, w okresie 1721-1825 (wiek deklarowany)/ Deaths at the age of 60 or more on a monthly basis, classified according to gender in the period 1721-1825 (declared age).

\begin{tabular}{|c|c|c|c|c|c|c|c|c|c|c|c|c|c|c|c|c|c|c|c|}
\hline \multirow{2}{*}{ Miesiąc } & \multicolumn{3}{|c|}{$60-69$} & \multicolumn{3}{|c|}{$70-79$} & \multicolumn{3}{|c|}{$80-89$} & \multicolumn{3}{|c|}{$90-99$} & \multicolumn{3}{|c|}{$100-119$} & \multicolumn{1}{|c|}{} \\
\cline { 2 - 7 } & $\mathrm{M}$ & $\mathrm{K}$ & $\mathrm{M}+\mathrm{K}$ & $\mathrm{M}$ & $\mathrm{K}$ & $\mathrm{M}+\mathrm{K}$ & $\mathrm{M}$ & $\mathrm{K}$ & $\mathrm{M}+\mathrm{K}$ & $\mathrm{M}$ & $\mathrm{K}$ & $\mathrm{M}+\mathrm{K}$ & $\mathrm{M}$ & $\mathrm{K}$ & $\mathrm{M}+\mathrm{K}$ & $\mathrm{M}$ & $\mathrm{K}$ & $\mathrm{M}+\mathrm{K}$ & Razem \\
\hline I & 39 & 36 & 75 & 17 & 11 & 28 & 4 & 6 & 10 & 2 & 2 & 4 & - & - & - & - & - & - & 117 \\
\hline II & 30 & 25 & 55 & 15 & 25 & 40 & 6 & 9 & 15 & 4 & - & 4 & - & - & - & - & - & - & 114 \\
\hline III & 46 & 39 & 85 & 18 & 21 & 39 & 6 & 12 & 18 & 1 & 2 & 3 & - & 1 & 1 & 1 & 0 & 1 & 147 \\
\hline IV & 43 & 35 & 78 & 22 & 16 & 38 & 7 & 3 & 10 & 3 & 3 & 6 & 1 & 1 & 2 & - & - & - & 134 \\
\hline V & 37 & 19 & 56 & 20 & 18 & 38 & 6 & 9 & 15 & 1 & 3 & 4 & 1 & - & 1 & - & - & - & 114 \\
\hline VI & 16 & 12 & 28 & 7 & 7 & 14 & 2 & 4 & 6 & 2 & - & 2 & - & - & - & - & - & - & 50 \\
\hline VII & 7 & 15 & 22 & 7 & 14 & 21 & 3 & 2 & 5 & 1 & 1 & 2 & - & 2 & 2 & - & - & - & 52 \\
\hline VIII & 20 & 14 & 34 & 12 & 15 & 27 & 3 & 4 & 7 & - & 2 & 2 & 1 & 1 & 2 & - & - & - & 72 \\
\hline IX & 15 & 14 & 29 & 7 & 13 & 20 & 1 & 7 & 8 & 2 & 2 & 4 & - & - & - & - & - & - & 61 \\
\hline X & 16 & 7 & 23 & 8 & 9 & 17 & 3 & 2 & 5 & 2 & 1 & 3 & - & - & - & - & - & - & 48 \\
\hline XI & 11 & 9 & 20 & 10 & 8 & 18 & 6 & 4 & 10 & 4 & 2 & 6 & 2 & - & 2 & - & - & - & 56 \\
\hline XII & 12 & 16 & 28 & 9 & 13 & 22 & 4 & 4 & 8 & 3 & 4 & 7 & - & - & - & - & - & - & 65 \\
\hline Razem 1.b. & 292 & 241 & 533 & 152 & 170 & 322 & 51 & 66 & 117 & 25 & 22 & 47 & 5 & 5 & 10 & 1 & 0 & 1 & 1030 \\
\hline$\%$ & $\mathrm{x}$ & $\mathrm{x}$ & 51,6 & $\mathrm{x}$ & $\mathrm{x}$ & 31,3 & $\mathrm{x}$ & $\mathrm{x}$ & 11,4 & $\mathrm{x}$ & $\mathrm{x}$ & 4,6 & $\mathrm{x}$ & $\mathrm{x}$ & 1,0 & $\mathrm{x}$ & $\mathrm{x}$ & 0,1 & 100 \\
\hline
\end{tabular}

Źródło: patrz tab. 1 
Tak jest i w naszym przypadku, nie zachowały się bowiem parafialne spisy wiernych. $Z$ tych samych względów nie możemy posłużyć się cząstkowymi współczynnikami zgonów według wieku ${ }^{52}$. W kolejnych 10-letnich przedziałach wiekowych odsetek zmarłych wyniósł kolejno: 31,3\%, 11,4\% i 4,6\% dla grupy 90-99 lat. W przypadku matuzalemów, to jest takich osób, które osiągnęły przynajmniej 100 lat odnotowano 11 przypadków. Proporcja płci osób zmarłych potwierdza $\mathrm{w}$ zasadzie znaną prawidłowość polegającą na nadumieralności kobiet, które częściej dożywały wieku starczego ${ }^{53}$. W przedziale 60-69 lat przewaga zmarłych należała jeszcze do mężczyzn - 55\%, jednak w dwóch kolejnych większość zmarłych stanowiły kobiety, odpowiednio: 53\% i 56\%. Zmarłych w wieku 90 lat i więcej było 58, w tym 31 mężczyzn. Poprawne wnioskowanie ogranicza tu jednak niewielka liczebność zbiorowości.

W gronie osób najstarszych, tj. takich które zmarły osiągnąwszy przynajmniej 100 lat życia znalazło się 11 osób. Wśród nich tylko dwaj mężczyźni przekroczyli ten wiek. Chodzi o Jana Ogórka, który zmarł 25 listopada 1798 r. w wieku 102 lat. Mieszkał we wsi Brzozowa Gać i został określony jako custos oppidum ${ }^{54}$. Absolutnym rekordzistą okazał się Michał Wyłosowski, mieszkaniec Kurowa, określony w źródle jako famatus. Zmarł 9 marca 1740 r. w wieku 113 lat ${ }^{55}$.

\section{Wiek rzeczywisty a wiek deklarowany}

Wiek zmarłych notowany w księgach metrykalnych nie zawsze był zgodny $\mathrm{z}$ rzeczywistym. Bardzo często mamy do czynienia $\mathrm{z}$ tzw. wiekiem deklarowanym, którego niedokładność polegała na tym, że był najczęściej zaokrąglany do pełnych dziesiątek. Rozbieżności te wynikały przede wszystkim z niewielkiej użyteczności wiedzy o dokładnej liczbie przeżytych lat. Z punktu widzenia dawnych społeczeństw, o wiele istotniejsza była wiedza na temat wieku sprawnego, co wiązało się z możliwością założenia rodziny. Równie ważnym było przejście w starość, z czym wiązało się najczęściej przekazanie gospodarstwa dzieciom. Etapy te były powiązane z biologią człowieka oraz sferą kulturową, a w zależności od miejsca i czasu mogły się różnićs ${ }^{56}$. W przypadku gdy nie znano dokładnej daty urodzenia, liczbę przeżytych lat ustalano odwołując się do pamięci bliskich, wyglądu zewnętrznego zmarłego, czasem wiek arbitralnie ustalała osoba odpowiedzialna za dokonanie zapisu $\mathrm{w}$ księdze metrykalnej. U ludzi starych ocena wieku była utrudniona, ponieważ brakowało osób mogących poświadczyć czas urodzenia, do tego dochodziła tzw. kokieteria starcza, czyli chwalenie się pode-

\footnotetext{
${ }^{52}$ Więcej na ten temat: Kuklo, Demografia Rzeczypospolitej, s. 406.

${ }^{53}$ Tamże, s. 408.

${ }^{54}$ AP Kurów, Liber mortuorum ecclesiae Kurowiensis ab anno 1797 ad annum 1809, s. 92.

${ }^{55}$ AP Kurów, [Liber metrices mortuorum ab anno 1698], s. 71.

${ }^{56}$ Górna, Śmierć ,ze starości”, s. 77-78. Więcej na ten temat zob.: C. Kuklo, Rodzina staropolska na tle europejskim. Podobieństwa i różnice rytmów rozwoju, PDP, 26 (2005) s. 27-46; M. Szołtysek, Dziedziczenie i międzypokoleniowa wymian w parafii Bujaków, 1766-1803, głos w dyskusji nad geografia europejskich form rodzinnych, PDP, 26 (2005) s. 79-116.
} 
szłym wiekiem. Czasami mogło się to wiązać z uzyskaniem korzyści materialnych $^{57}$.

Brak precyzji wieku deklarowanego przejawiało się głównie w jego zaokrąglaniu, przy czym skupienie wieku koncentrowało się na pełnych dziesiątkach (tab. 4 i ryc. 1$)$.

Tabela 4. Skupienia wieku zmarłych (deklarowanego) w latach 1721-1825/ Frequency of the occurrence of the same declared age in the years 1721-1825.

\begin{tabular}{|c|c|c|c|c|}
\hline \multirow[t]{2}{*}{ Wiek deklarowany } & \multicolumn{2}{|c|}{$\mathbf{M}$} & \multicolumn{2}{|c|}{$\mathbf{K}$} \\
\hline & L. b. & $\%$ & L.b. & $\%$ \\
\hline 60 & 188 & 66,7 & 166 & 68,9 \\
\hline $55-64$ & 282 & 100 & 241 & 100 \\
\hline 70 & 107 & 54,3 & 123 & 60,3 \\
\hline $65-74$ & 197 & 100 & 204 & 100 \\
\hline 80 & 31 & 53,4 & 51 & 65,4 \\
\hline $75-84$ & 58 & 100 & 78 & 100 \\
\hline 90 & 20 & 60,6 & 16 & 61,5 \\
\hline $85-94$ & 33 & 100 & 26 & 100 \\
\hline 100 & 4 & 57,1 & 5 & 62,5 \\
\hline $95-104$ & 7 & 100 & 8 & 100 \\
\hline 110 & 0 & - & 0 & - \\
\hline $105-114$ & 1 & 100 & 0 & - \\
\hline 0 & 350 & 60,6 & 361 & 64,8 \\
\hline $55-114$ & 578 & 100 & 557 & 100 \\
\hline
\end{tabular}

Źródło: patrz tab. 1.

Ryc. 1. Wiek deklarowany w chwili zgonu w okresie 1721-1825/ Declared age at the moment of death in the years 1721-1825.

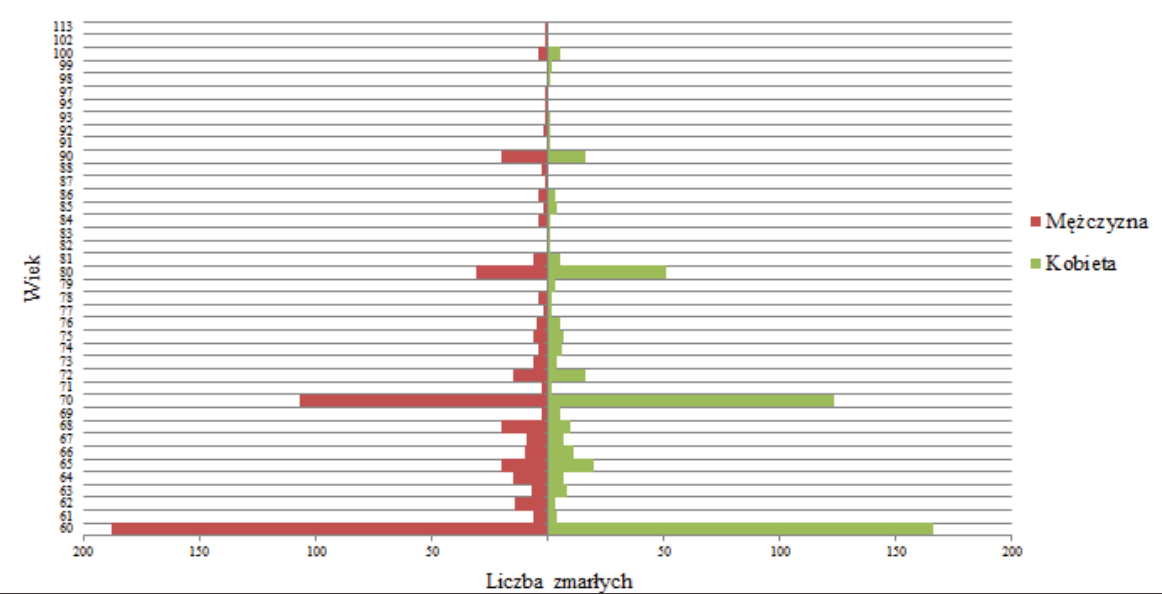

Źródło: patrz tab. 1.

${ }^{57}$ Górna, Śmierć ,,ze starości”, s. 78; Zieliński, Ludzie starzy, s. 108. 
Powyższe zestawienia dowodzą braku dokładności w określaniu wieku zmarłego notowanego w źródłach. Obserwowane skupienia wieku dotyczą lat zaokrąglanych do pełnych dziesiątek. Najsilniejsza koncentracja, zarówno w przypadku mężczyzn jak i kobiet dotyczyła 60. roku życia i była nieco wyższa u kobiet odpowiednio: $66,7 \%$ i $68,9 \%$. Dotyczy to także pozostałych przedziałów wiekowych. W sumie, w całym badanym okresie, aż 60,6\% określeń wieku w zgonach mężczyzn kończyło się na 0 . W przypadku kobiet wartość ta była jeszcze wyższa $-64,8 \%{ }^{58}$.

Zastosowana powyżej metoda grupowania wieku zmarłych wskazuje na niedociągnięcia ówczesnej statystyki, nie pozwala jednak na ustalenie dokładnej skali zjawiska oraz różnicy lat między wiekiem deklarowanym a rzeczywistym. Odpowiedzi na te pytania może dopiero dostarczyć konfrontacja metryk zmarłych z odpowiednimi wpisami w metrykach chrztów. Jednak i w takim przypadku napotykamy na szereg ograniczeń. Oprócz sytuacji gdy źródła zaginęły lub zostały zniszczone, należy zwrócić uwagę, iż nie wszystkie osoby zarejestrowane w księdze zmarłych zostały wcześniej ujęte w księgach ochrzczonych (urodzili się poza parafią, fakt ich narodzin nie został zgłoszony przez rodziców, metryka nie została sporządzona wskutek zaniedbania osób prowadzących stosowną dokumentację). Kolejny problem stanowi identyfikacja osób za pomocą nazwiska (przezwiska) w sytuacji, gdy proces ich tworzenia i dziedziczenia w odniesieniu do chłopów zakończył się dopiero w XIX wieku. Dodatkowe utrudnienia pojawiają się także gdy chcemy zweryfikować wiek kobiet zamężnych. W przypadku braku nazwiska panieńskiego w metryce zgonów poprawna identyfikacja staje się niemożliwa.

Ustalenie faktycznego wieku zmarłych w oparciu o konfrontację zapisów w księgach zgonów i urodzeń, ograniczyliśmy do osób najstarszych, tj. tych które dożyły przynajmniej 91 lat. Do weryfikacji tej nie można jednak podchodzić bezkrytycznie, co wynika z lakoniczności danych odnotowanych w metrykach zgonów $^{59}$. W badanym okresie, w księgach zgonów odnotowano 22 takie osoby. Spośród nich tylko w trzech przypadkach udało się zweryfikować faktyczny wiek zmarłych za pomocą wpisów w księgach ochrzczonych. Ze wspomnianej trójki najdłużej żył Jan Ogórek z Brzozowej Gaci. W metryce zgonu zanotowano, iż zmarł 25 XI 1798 r., przeżywszy 102 lata $^{60}$. Chrzest Jana Ogórka odbył się w 1701 roku, a więc faktyczny wiek zmarłego to 97 lat $^{61}$. Sprawę komplikuje fakt, iż w księdze urodzeń znajdujemy jeszcze dwa wpisy chrztu Jana Ogórka. Ich daty są zbliżone, tj. pochodzą z 1703 i 1705 roku $^{62}$. W każdym przypadku inni byli rodzice chrzczonego dziecka, co wyklucza sytuację, w której nadawano imię dziecka

${ }^{58}$ Por.: Szkutnik, Dlugowieczni mieszkańcy, s. 132; Górna, Śmierć „,ze starości”, s. 79. Analizowany wiek zmarłych można weryfikować w oparciu o zapisy w księgach ochrzczonych, wymaga to jednak dalszych żmudnych badań. Sprawę komplikuje dodatkowo fakt, iż w przypadku kobiet brak w źródle informacji o nazwisku panieńskim.

${ }^{59}$ Brak m. in. personaliów rodziców osób zmarłych.

${ }^{60} \mathrm{AP}$ Kurów, Liber metrices mortuorum ecclesiae parochialis Kuroviensis ab anno 1782 ad annum 1811, s. 92.

${ }^{61}$ AP Kurów, [Liber metrices baptisatorum ab anno 1691], s. 100.

${ }^{62}$ AP Kurów, [Liber metrices...], s. 119, 150. 
po wcześniej zmarłym potomku. Z kolei metryka zgonu Wojciech Swaczyny informuje, iż zmarł on 1 XII 1800 r. w wieku 95 lat ${ }^{63}$. Jego chrzest odbył się w 1704 roku $^{64}$, a więc wiek podany w metryce zgonu pokrywa się $\mathrm{z}$ faktycznym.

\section{Sezonowość zgonów}

Natężenie umieralności związane jest $\mathrm{z}$ wieloma czynnikami o wzajemnym oddziaływaniu. Należy do nich zaliczyć przede wszystkim: klimat, choroby występujące na danym terenie, poziom opieki medycznej, sposób odżywiania. Za podstawowy regulator zmienności natężenia zgonów w cyklu rocznym uważa się często klimat, a w szczególności temperaturę powietrza i opady deszczu ${ }^{65}$. Istotną rolę odgrywają choroby. W przypadku dzieci, poza oczywistym wpływem sezonowości urodzeń, istotną rolę odgrywały schorzenia układu pokarmowego typu dyzenteria, czerwonka, biegunki, których często młody organizm nie potrafił zwalczyć. Wynikały one z kolei z niskiego poziomu ogólnej higieny, także niskiej świadomości matek karmiących. Nasilenie zgonów najmłodszych stwierdzono w miesiącach letnich, od czerwca do września włącznie. Tak było np. w parafii Bejsce, czy XVIII-wiecznej Warszawie, gdzie szczyt umieralności najmłodszych przypadał na sierpień ${ }^{66}$.

W przypadku ludzi starych wzmożoną umieralność obserwowano najczęściej w miesiącach zimowych, a znaczną rolę odgrywały choroby układu sercowo-krążeniowego i oddechowego. W dwóch parafiach poznańskich - św. Marii Magdaleny oraz parafii Św. Krzyża - nadwyżkę zgonów odnotowano w grudniu i styczniu. Wśród przyczyn zgonów podawano często starość, puchlinę, słabość, zapalenie płuc. Wszystkie one mogły mieć związek z przewlekłymi schorzeniami, w tym układu krążenia i płuc. Niska temperatura sprzyjała zapewne częstszym infekcjom górnych dróg oddechowych, co potęgowało objawy chorób przewlekłych, a te $\mathrm{z}$ kolei wskutek zaostrzenia kończyły się śmiercią ${ }^{67}$. Dodatkowy, niekorzystny wpływ, miało także wycieńczenie starczych organizmów wskutek niedożywienia na przednówku (grupa osób 60 lat i więcej), co z kolei skutkowało nasileniem zgonów w kwietniu ${ }^{68}$.

Rozpatrując ogólną sezonowość zgonów w parafii Kurów (ryc. 2) widać dwa okresy nasilenia umieralności; pierwszy, w miesiącach zimowo-wiosennych (styczeń-kwiecień) oraz drugi w lecie (sierpień). Najwyższą wartość wskaźnik sezonowości osiągnął w kwietniu - 136,3. Od miesiąca maja natężenie zgonów spadało, znaczące odbicie nastąpiło w sierpniu - 100,1, po czym znów nastąpił

${ }^{63}$ AP Kurów, Liber mortuorum ecclesiae Kurowiensis ab anno 1797 ad annum 1809, s. 137.

${ }^{64}$ AP Kurów, [Liber metrices baptisatorum ab anno 1691], s. 116.

${ }^{65}$ Liczbińska, Umieralność i jej uwarunkowania, s. 95; Piasecki, Ludność parafii, s. 130.

${ }^{66}$ Kuklo, Demografia Rzeczypospolitej, s. 410-411.

${ }^{67}$ Liczbińska, Umieralność i jej, s. 105. Por.: Kuklo, Demografia Rzeczypospolitej, s. 411; Piasecki, Ludność parafii, s. 126-133.

${ }^{68}$ Kuklo, Demografia Rzeczypospolitej, s. 411. 
spadek. W kolejnych miesiącach, aż do grudnia, wartość wskaźnika wahała się między 74,6 a $84,5^{69}$.

Ryc 2. Sezonowośc zgonów w okreise 1698-1825*/ The seasonality of deaths in the years 1698-1825.

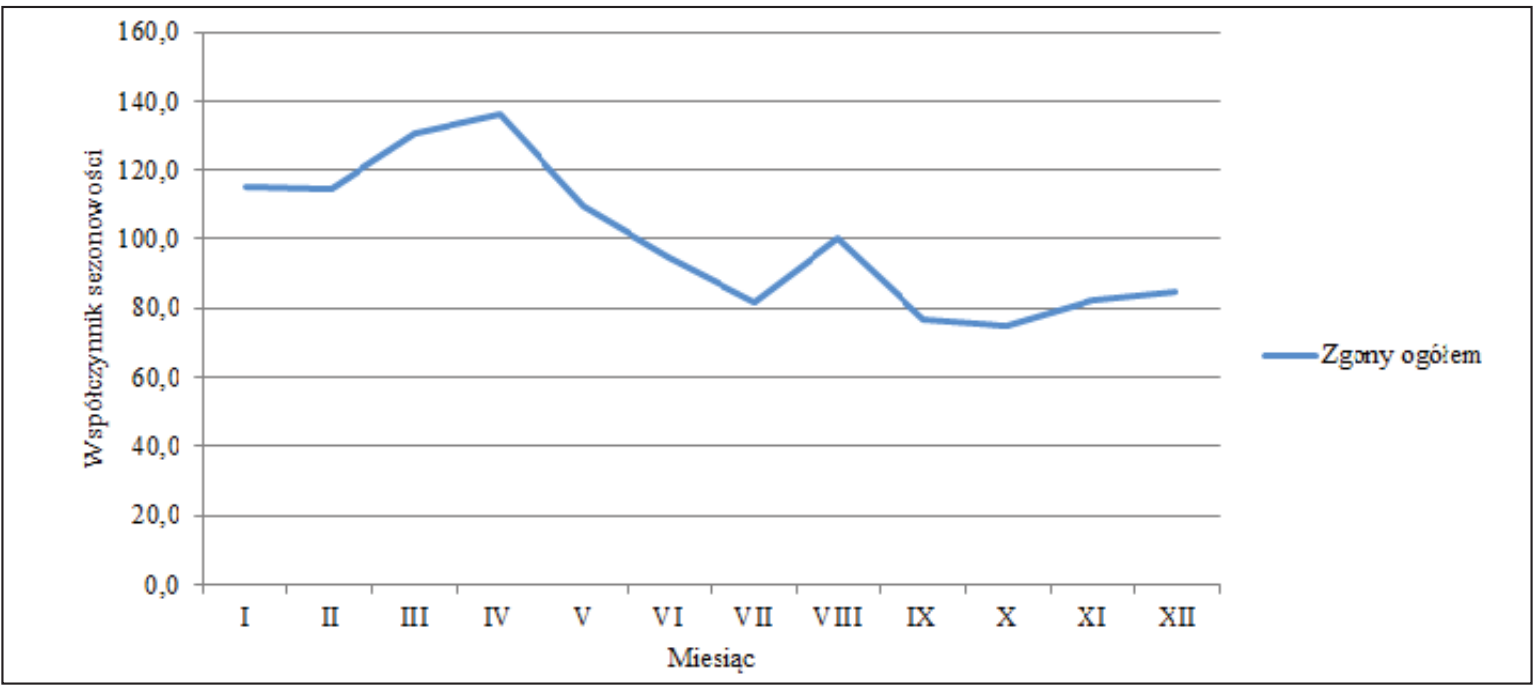

Źródło: patrz tab.1.

*- dane dla osób w wieku 60 i więcej lat pochodzą okresu 1721-1825. Uwaga ta odnosi się także do kolejnych zestawień.

W przypadku rozkładu miesięcznego zgonów ludzi starych szczegółowe dane prezentuje tab. 5 .

Tabela 5. Sezonowość miesięczna zgonów w wieku 60 lat i więcej (wiek deklarowany)/ Monthly seasonality of deaths at the age of 60 and more (declared age).

\begin{tabular}{|c|c|c|c|c|c|c|c|c|c|c|c|c|c|}
\hline Iata & I & $\mathbb{I}$ & II & IV & V & VI & VII & VIII & X & X & XI & XII & Razam \\
\hline $1721-1730$ & - & - & - & - & 2 & - & - & - & - & - & - & - & 2 \\
\hline $1731-1740$ & 10 & 3 & 1 & 10 & 2 & - & 2 & 2 & 2 & 1 & - & 2 & 35 \\
\hline $1741-1750$ & 3 & 3 & 5 & 5 & 10 & 2 & 8 & 4 & 1 & 5 & 5 & 5 & 56 \\
\hline $1751-1760$ & 11 & 8 & 11 & 19 & 9 & 6 & 5 & 12 & 6 & 5 & 7 & 2 & 101 \\
\hline $1761-1770$ & 10 & 16 & 20 & 10 & 6 & 2 & 2 & 8 & 7 & 8 & 4 & 8 & 101 \\
\hline $1771-1780$ & 10 & 10 & 10 & 5 & 11 & 6 & 2 & 9 & 4 & 5 & 2 & 2 & 76 \\
\hline $1781-1790$ & 6 & 19 & 21 & 20 & 18 & 5 & 7 & 10 & 12 & 3 & 9 & 4 & 134 \\
\hline $1791-1800$ & 24 & 10 & 32 & 23 & 15 & 12 & 5 & 9 & 9 & 6 & 8 & 18 & 171 \\
\hline $1801-1810$ & 17 & 20 & 18 & 17 & 20 & 9 & 5 & 8 & 8 & 11 & 11 & 8 & 152 \\
\hline $1811-1820$ & 21 & 17 & 21 & 13 & 17 & 5 & 10 & 6 & 10 & 2 & 5 & 12 & 139 \\
\hline $1821-1825$ & 5 & 8 & 8 & 12 & 4 & 3 & 6 & 4 & 2 & 2 & 5 & 4 & 63 \\
\hline Razm & 117 & 114 & 147 & 134 & 114 & 50 & 52 & 72 & 61 & 48 & 56 & 65 & 1030 \\
\hline L p & 133,6 & 142,8 & 167,8 & 158,1 & 130,1 & 59,0 & 59,4 & 82,2 & 72,0 & 54,8 & 66,1 & 742 & 1200,0 \\
\hline
\end{tabular}

Źródło: patrz tab. 1.

${ }^{69} \mathrm{~W}$ celu wytrącenia niejednakowej liczby dni w poszczególnych miesiącach dokonano standaryzacji. Technikę obliczenia wskaźnika sezonowości omówiono szerzej w: Kuklo, Demografia Rzeczypospolitej, s. 162-163. 
Największe natężenie zgonów miało miejsce w marcu - 167,8, następnie w kwietniu - 158,1 oraz w lutym - 142,8. Z kolei najniższe wartości wskaźnika sezonowości zgonów odnotowano w październiku i czerwcu. W nieodległej parafii Opole w latach 1771-1800 najwięcej zgonów przypadało na luty i marzec, najmniej zaś na wrzesień i październik ${ }^{70}$.

Analizując rozkład miesięczny zgonów ludzi starych uwagę zwraca jego zróżnicowanie jeżeli chodzi o płeć (ryc. 3).

Ryc. 3. Sezonowość zgonów w wieku 60 lat i więcej z podzialem na płeć w latach 17211825/ Deaths at the age of 60 or more on a monthly basis, classified according to gender in the period 1721-1825 (declared age).

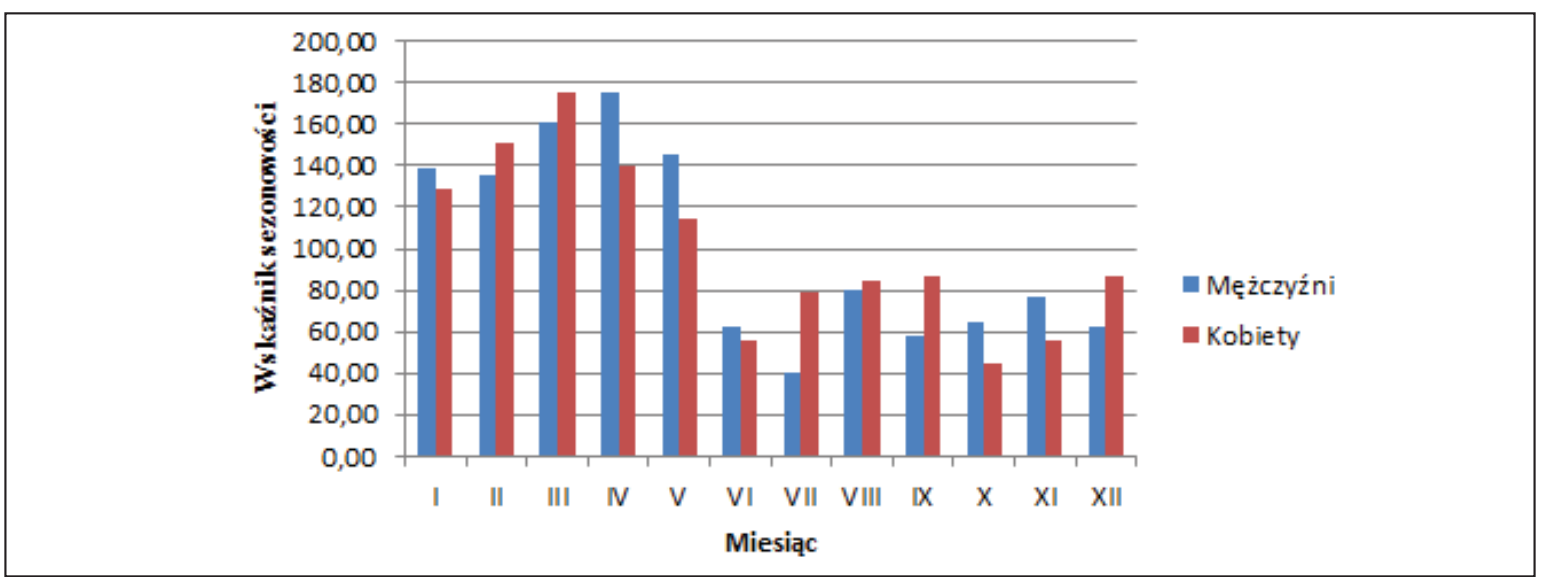

Źródło: patrz tab. 1.

W przypadku mężczyzn najwięcej zgonów odnotowano w kwietniu - wskaźnik 175,6, marcu - 160,9 oraz maju - 145,3. U kobiet najwyższą wartość wskaźnik osiągnął w marcu - 174,9, następnie w lutym - 151 i kwietniu - 139,8. Zarówno w przypadku mężczyzn jak i kobiet wzmożoną umieralność notowano w miesiącach zimowych oraz na przednówku, co potwierdza wspomniane wyżej implikacje związane z głodami przednówkowymi.

Różnice w sezonowości zgonów widoczne są także, gdy porównamy ludzi starych z klasy 60-79 lat z populacją w wieku 80 lat i więcej, a więc grupą którą możemy nazwać długowiecznymi czy też sędziwymi (ryc. 4).

Ryc. 4. Sezonowośc zgonów w latach 1721-1825/ The seasonality of deaths in the years 1721-1825.

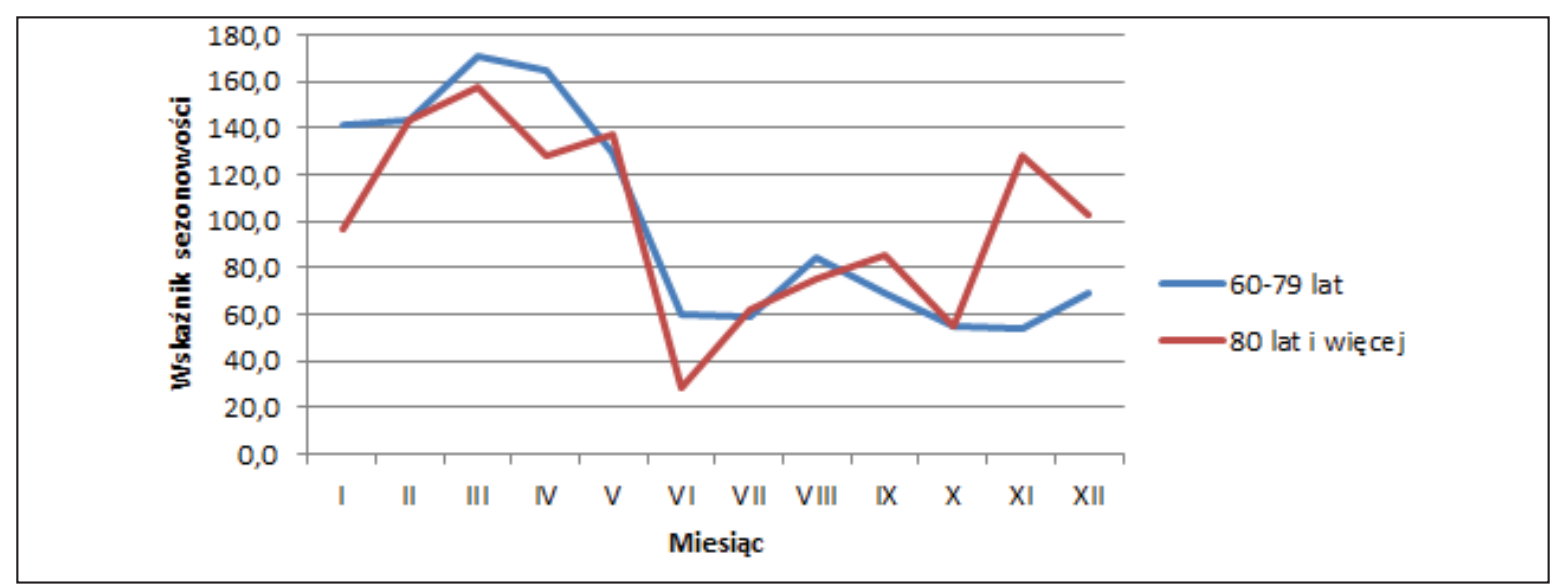

Źródło: patrz tab. 1.

${ }^{70}$ Szkutnik, Długowieczni mieszkańcy, s. 142. 
W przypadku tych pierwszych najwyższe wartości wskaźnik osiągnął w miesiącu marcu - 170,6 oraz kwietniu - 164,9. Ludzie długowieczni najczęściej umierali w marcu, ale wzrost umieralności odnotowano także w listopadzie oraz grudniu, odpowiednio - 127,8 i 103,1, czego nie zaobserwowano z kolei w przypadku osób, które zmarły przed 80 . rokiem życia. Wiązało się to zapewne z faktem, iż organizmy ludzi najstarszych były bardziej wrażliwe na czynniki biologiczne. Wraz z nastaniem późnojesiennych chłodów rosła zachorowalność na choroby układu oddechowego, co w konsekwencji skutkowało wzmożoną śmiertelnością.

\section{Podsumowanie}

W badanym okresie zmarło 6633 osoby, w przypadku 339 nie odnotowano wieku. 1030 zmarłych to ludzie starzy, tj. mający 60 lat i więcej. Początkowo rejestracja wieku zmarłego była zawodna, wyraźna poprawa w tym zakresie nastąpiła w latach 20. XVIII wieku. Wskaźniki dynamiki demograficznej dla kolejnych dziesięcioleci świadczą z kolei o nierejestrowaniu części zgonów, w związku z tym do otrzymanych przez nas wyników należy podchodzić z dużym krytycyzmem. Wiek denata podawano często w przybliżeniu, o czym świadczy fakt, iż ponad 60\% określeń kończyło się na latach pełnych - zakończonych zerem. Analiza sezonowości zgonów starców ujawniła, iż najczęściej umierali oni w miesiącach zimowych oraz na przednówku, a w przypadku ludzi najstarszych, tj. powyżej 80 roku życia, także w okresie późnojesiennym.

Słowa kluczowe: Kurów, parafia, archiwum, księgi metrykalne, ruch naturalny, sezonowość zgonów

\section{BIBLIOGRAFIA}

\section{Źródła rękopiśmienne}

Archiwum parafialne w Kurowie

[Liber metrices mortuorum ab anno 1698]

[ Liber metrices mortuorum ab anno 1748]

Liber metrices mortuorum ecclesiae parochialis Kuroviensis ab anno 1782 ad annum 1811;

[Liber natorum ab anno 1807]

[Księgi zgonów od 1812 do 1825 roku]

\section{Opracowania}

Balicki J., Frątczak B., Nam E., Ch., Przemiany ludnościowe. Fakty-interpretacje-opinie, Warszawa 2007.

Boreczek K. A., Kurów od początku XVIII do połowy XX wieku. Część pierwsza 17001918, Lublin 1996.

Chojecki D.K., Od społeczeństwa tradycyjnego do nowoczesnego. Demografia i zdrowotność głównych ośrodków miejskich Pomorza Zachodniego w dobie przyspieszonej industrializacji i urbanizacji w Niemczech (1871-1913), Szczecin 2014. 
Daszkiewicz-Ordyłowska D., Zgony w parafii toszeckiej w latach 1789-1877,w: „Śląskie Studia Demograficzne”, t. 3: Zgony, red. Z. Kwaśny, Wrocław 1996, s. 27-43.

Gawrysiakowa J., Badania demograficzne w parafii Bochotnica Kościelna, „Przeszłość Demograficzna Polski”, 8 (1975) s. 81-124.

Gawrysiakowa J., Grupy wyznaniowe ludności w Lubelskiem w XIX wieku, Lublin 1992.

Gieysztorowa I., Niebezpieczeństwa metodyczne polskich badan metrykalnych XVII -XVIII wieku, „Kwartalnik Historii Kultury Materialnej”, 19 (1971) s. 557-603

Górna K., Śmierć „ze starości” - o ludziach starych i długowiecznych na podstawie wybranych metryk śląskich z XVIII i pierwszej połowy XIX wieku, „Przeszłość Demograficzna Polski”, 29 (2010) s. 69-98.

Guzowski P., Starość w życiu kmieci polskich przełomu średniowiecza i czasów nowożytnych, „Kwartalnik Historii Kultury Materialnej”, 58 (2010) nr 1, s. 101-110.

Handelsman M., Z. Nagórski Z., Wieś Bochotnica Kościelna pod względem ludnościowym, cz. 1-2, „Ekonomista”, 4 (1904) s. 44-68, 223-234.

Jaworski M., Dzieje parafii rzymskokatolickiej w Kurowie w latach 1773-1976, Lublin 1991 [mps pracy magisterskiej, Archiwum Uniwersyteckie KUL].

Jop S., Ludność na terenie parafii Ostrów Lubelski w ostatniej ćwierci XVIII wieku, „Przeszłość Demograficzna Polski”, 6 (1974) s. 53-84.

Kędelski M., Umieralność i trwanie życia ludności Wielkopolski w XIX wieku, Poznań 1996.

Kopczyński M., Cykl życia jednostek na wsi schyłku XVIII wieku, „Studia Demograficzne", 127 (1997) nr 1, s. 97-115.

Kopczyński M., Ludzie starzy w chłopskich i szlacheckich gospodarstwach domowych w Koronie u schyłku XVIII wieku, „Kwartalnik Historii Kultury Materialnej”, 58 (2010) nr 1, s. 111-119.

Kopczyński M., Starość nie radość? Ludzie starzy na wsi kujawskiej u schyłku XVIII wieku, ,Zapiski Historyczne”, 61 (1996) s. 45-64.

Kopczyński M., Studia nad rodziną chłopską w Koronie w XVII-XVIII wieku, Warszawa 1998.

Kościół i społeczeństwo Małopolski w II połowie XVIII w. Materiały źródłowe, t. 1, Ludność i organizacja diecezji krakowskiej, oprac. B. Szady, Lublin 2010.

Kuklo C., Gospodarstwo domowe osób starszego pokolenia w miastach na ziemiach polskich w epoce późnofeudalnej, „Kwartalnik Historii Kultury Materialnej”, 58 (2010) nr 1, s. 121-133.

Kuklo C., Kobieta samotna w społeczeństwie miejskim u schyłku Rzeczypospolitej szlacheckiej. Studium demograficzno-społeczne, Białystok 1998

Kuklo C., Ludzie starzy w miastach i miasteczkach Rzeczypospolitej szlacheckiej, w: Gospodarka, ludzie, władza. Studia ofiarowane Juliuszowi Łukasiewiczowi w 75. Rocznice urodzin, red. M. Kopczyński, A. Mączak, Warszawa 1998, s. 137-155.

Kuklo C., Rodzina staropolska na tle europejskim. Podobieństwa i różnice rytmów rozwoju, „Przeszłość Demograficzna Polski”, 26, 2005, s. 27-46.

Kuklo C., Rodzina w osiemnastowiecznej Warszawie, Białystok 1992

Kuklo C., Urodzić się i zestarzeć w mieście polskim, w: Między Zachodem a Wschodem. Studia ku czci profesora Jacka Staszewskiego, t. 2, red. J. Dumanowski i in., Toruń 2003, s. 345-353.

Kurowska H., Gubin i jego mieszkańcy. Studium demograficzne XVII-XIX w., Zielona Góra 2010.

Liczbińska G., Umieralność i jej uwarunkowania wśród katolickiej i ewangelickiej ludności historycznego Poznania, Poznań 2009. 
Opas T., Sytuacja ludności żydowskiej w miastach szlacheckich województwa lubelskiego w XVIII wieku, „Biuletyn Żydowskiego Instytutu Historycznego”, 62 (1968) s. 3-35.

Piasecki E., Ludność parafii bejskiej (woj. kieleckie) w świetle ksiąg metrykalnych z XVIII-XX w. Studium demograficzne, Warszawa-Wrocław 1990.

Poniat R., Służba domowa w miastach na ziemiach polskich od połowy XVIII do końca XIX wieku, Warszawa 2014.

Rejman S., Ludność podmiejska Rzeszowa w latach 1784-1880. Studium demograficzno -historyczne, Rzeszów 2006.

Rodecki F., Tabella miast, wsi, osad Królestwa Polskiego z wyrażeniem ich położenia i ludności alfabetycznie ułożona w Biórze Kommissyi Rządowey Spraw Wewnętrznych i Policyi, Warszawa 1830.

Rosset E., Proces starzenia się ludności. Studium demograficzne, Warszawa 1959.

Staręga-Piasek J., Lissowski A., Starość psychospołeczna, w: Starość psychospołeczna i potrzeby opieki medycznej ludzi starych, Warszawa 1985, s. 13-124.

Sułowski Z., Księga zgonów parafii Kijany i Bystrzyca z drugiej połowy XVIII w., „Archiwa Biblioteki i Muzea Kościelne", 67 (1997) s. 271-299.

Szafran P., Rozwój średniowiecznej sieci parafialnej w Lubelskiem, Lublin 1958.

Szkutnik P., Długowieczni mieszkańcy parafii Opole Lubelskie w końcu XVIII wieku w świetle metryk pochówków (pogrzebów), w: Społeczno-gospodarcze uwarunkowania i konsekwencje wydłużania życia ludzkiego w Europie Srodkowej w czasach nowożytnych, Zielona Góra 2011, s. 123-147.

Szołtysek M., Biskup D., Różnorodność czy tożsamość? Chłopskie gospodarstwo domowe na ziemiach Rzeczypospolitej i Śląska pod koniec XVIII wieku, w: Rodzina i gospodarstwo domowe na ziemiach polskich w XV-XX wieku. Struktury demograficzne, społeczne i gospodarcze, red. C. Kuklo, Warszawa 2008, s. 363-390.

Szołtysek M., Dziedziczenie i międzypokoleniowaa wymian w parafii Bujaków, 17661803, głos w dyskusji nad geografią europejskich form rodzinnych, „Przeszłość Demograficzna Polski”, 26 (2005) s. 79-116.

Szołtysek M., Struktura gospodarstwa domowego w Koronie i na Litwie a funkcje rodziny w końcu XVIII wieku: rozbieżność czy podobieństwo?, w: Rodzina, gospodarstwo domowe i pokrewieństwo na ziemiach polskich w perspektywie historycznej - ciągłość czy zmiana?, red. Kuklo C., Warszawa 2012, s. 173-208.

Śladkowski W., Pod zaborem austriackim, w Księstwie Warszawskim i Królestwie Polskim 1795-1831, w: Dzieje Lubelszczyzny, t. 1, red. T. Mencel, Warszawa 1974, s. 483-542.

Wiercieński H., Opis statystyczny guberni lubelskiej, Warszawa 1901.

Wyżga M., Ludzie starzy w podkrakowskiej parafii Raciborowice w XVIII wieku, w: Społeczno-gospodarcze uwarunkowania i konsekwencje wydłużania życia ludzkiego w Europie Środkowej w czasach nowożytnych, red. H. Kurowska, Zielona Góra 2011, s. 113-121.

Wyżga M., Parafia Raciborowice od XVI do końca XVIII wieku. Studium o społeczności lokalnej, Kraków 2011.

Zielińska A., Przemiany struktur demograficznych w Toruniu i na początku XX wieku, Toruń 2012.

Zieliński M.G., Ludzie starzy i sędziwi w świetle ksiąg metrykalnych parafii chełmińskiej z przełomu XVII-XVIII w., w: Kondycja zdrowotna i demograficzna społeczeństwa polskiego na przestrzeni wieków, red. K. Mikulski, A. Zielińska, K. Pękacka-Falkowska, Toruń 2011, s. 106-114.

Zyblikiewicz L.A., Kobieta w Krakowie w 1880 r. w świetle ankiet powszechnego spisu ludności. Studium demograficzne, Kraków 1999. 


\title{
DEMOGRAPHIC STUDIES OF OLD PEOPLE IN THE REGION OF LUBLIN IN THE LIGHT OF DEATH RECORDS (SOME ASPECTS).PART I. KURÓW (1698-1825)
}

\begin{abstract}
Summary
The article presents the problem of the elderly in the parish of Kurów for over two centuries. The parish, which dates back to the fifteenth century, had more than 2150 Catholics in 1787. In the period under study, 6633 people died, in case of 339 no age was given. 1030 dead people were old ones, that is, being 60 years old or more. Initially, the registration of the age of the deceased was unreliable, a marked improvement in that area took place in the 1720s. The author pointed out that the age of the deceased recorded in registers was so-called ,declared age", as evidenced by the fact that in many cases the given age ends in 0 . The recorded age was rounded to the nearest ten in $60 \%$ of cases. An analysis of the seasonality of deaths of the elderly revealed that they died mostly during winter and pre-harvest season.
\end{abstract}

Keywords: Kurów, parish, archive, registers, natural movement, the seasonality of deaths 